\title{
Farmers' Social Life that affect Loan Repayment: A Study of Cocoa Farmers in Ikom Local Government Area of Cross River State
}

\author{
Uduma, M. K. \\ Department of Agricultural Education \\ Federal College of Education \\ Obudu, CRS, Nigeria
}

\begin{abstract}
The social life of cocoa farmer that affect loan repayment capacity was studied. From all cocoa farmers in Ikom, 70 farmers whose farm size measured up to five hectares and who made use of loan during the 2004 farming season were purposively sampled for the study. Social factors as age, household size, level of education, farming experience and marital status as dummy variable were regressed on loan repayments. The objective was to identify those social factors that affect loan repayment and to determine the significance of these social factors on loan repayment. Age, household size and farming experience were significant while level of education and marital status were insignificant. The work recommends that age, household size and farming experience of a farmer should be considered as necessary criteria for loan disbursement.
\end{abstract}

\section{Background and Problem}

Nigerian agriculture is characterized by use of crude tools and implements, low output, low returns, low level capacity to satisfy the food and fibre needs of the nation and hence low income, low savings and investment - the viscous poverty cycle. Meaningful agricultural development requires transformation from traditional to modern technique. This in turn, demands investment of capital. The majority of farmers in this country is poor and cannot on their own meet the level of financial demands of their farms. The remedy often perceived is to seek for loan. Credit, has therefore become a significant feature in this sector of the economy.

Borrowing creates debts, which must be repaid or carried over as liabilities that often reduces credit image. Various social characteristics are expected to influence the repayment of loans by farmers. Balogun and Otu (1991) remarked that in small holder farming, credit use and repayment capacity is determined by household size. Arene (1990) and Mejieha (1991) found age to be significant in loan repayment.

\section{Objective of the Study}

The objective of this study is to examine the effects of some social characteristics of the cocoa farmer borrower that affect his/her loan repayment capacity. The specific objectives are to:

i. identify the social factors that affect loan repayment

ii. determine the significance of the social factors on loan repayment, and

iii. state the economic/policy implications of the study.

\section{Hypothesis}

To guide the study, one null hypothesis tested at both 0.01 and 0.05 levels of significance was formulated thus: "farmers' social life have no significant effect on repayment".

\section{Methodology}

From all cocoa farmers in Ikom Local Government Area, 70 whose farm size measured up to five hectares and who made use of loan during the 2004-farming season were purposively sampled for the study. Five hectares of cocoa farm is considered ideal for commercial production. Data for the study was collected from primary source using a set of structured questionnaire validated by three experts in the department of agriculture. The questionnaire was administered personally by the researcher to cocoa farmer who made use of loan during the year 2004 . The questionnaire was designed specifically to collect data on social characteristics affecting loan repayment. The objective of the study was achieved by analyzing the data using production function. The production function model measured and estimated loan repayment $(\mathrm{Y})$ as a function of social variables $\left(\mathrm{X}_{1}\right)$. The model is implicitly specified as follows:

$\mathrm{Y}=\mathrm{f}\left(\mathrm{X}_{1}, \mathrm{X}_{2}, \mathrm{X}_{3}, \mathrm{X}_{4}, \mathrm{X}_{5}\right)+\mathrm{e}$ 
Where

$\mathrm{X}_{1}$, = age of cocoa farmer borrower (years)

$\mathrm{X}_{2},=$ household size of the borrower

$\mathrm{X}_{3},=$ level of education of borrower (years)

$\mathrm{X}_{4},=$ farming experience (years)

$\mathrm{X}_{5}=$ marital status of borrower as dummy variable married 1, Unmarried, 0

$\mathrm{E}=$ error term.

\section{Results and Discussion}

\section{Age of Farmer Borrower}

The age distribution of farmer borrower is shown on Table 1. The table shows that majority (54.28\%) of the respondents fell within age range of between $50-59$ years.

Table 1: Age Distribution of Farmer Borrower and Repayment Rate

\begin{tabular}{|l|l|l|l|l|}
\hline Age Range & Frequency & \% & \multicolumn{2}{|l|}{ Repayment Rate } \\
\hline & & & $\mathbf{1 - 9 9 \%}$ & $\mathbf{1 0 0 \%}$ \\
\hline$<40$ & 6 & 8.57 & - & - \\
$40 \quad-49$ & 22 & 31.4 & 12 & 4 \\
$50-59$ & 38 & 54.28 & 8 & 10 \\
$>60$ & 4 & 5.7 & 6 & 30 \\
\hline $\begin{array}{l}\text { Total } \\
\text { \% }\end{array}$ & $\mathbf{7 0}$ & $\mathbf{1 0 0}$ & $\mathbf{2 6}$ & $\mathbf{4 4}$ \\
\hline
\end{tabular}

Result on table 1 indicates that loan repayment increases with age. That is, older farmers show more willingness to repay than the younger farmers.

\section{Household Size of Farmer Borrowers}

Results of the study revealed that $42.85 \%$ of the farmers have household size of about $7-9,21.4 \%$ of the farmers studied have household size above 9 while $28.57 \%$ of the farmers have household size of $4-6$.

Table 2: Household Size Distribution of Farmer Borrowers and Repayment Capacity

\begin{tabular}{|l|l|l|l|l|}
\hline Household Size & Frequency & \% & Repayment Rate \\
\hline & & & $\mathbf{1}-\mathbf{9 9 \%}$ & $\mathbf{1 0 0 \%}$ \\
\hline $1-3$ & 2 & 2.85 & 30 & 10 \\
$4-6$ & 20 & 28.57 & 13 & 5 \\
$7-9$ & 33 & 47.14 & 4 & 3 \\
9 & 15 & 21.42 & 3 & 2 \\
\hline Total & $\mathbf{7 0}$ & $\mathbf{1 0 0}$ & $\mathbf{5 0}$ & $\mathbf{2 0}$ \\
\% & & & $\mathbf{7 1 . 4 2 \%}$ & $\mathbf{2 8 . 5 7 \%}$ \\
\hline
\end{tabular}

Result of the study on table 2 indicates that loan repayment decreases as household size increases. It is obvious that the higher the number of dependents, the more the household expenses and hence the less the capacity to repay.

\section{Farming Experience of Farmer Borrowers}

Table 3 shows the farming experience of farmer borrowers in relation to their repayment capacity. Majority (45.7\%) of the farmer borrowers fell within the range of between $16-25$ years of farming experience, while the lowest (11.4\%) fell with above 30 years of farming experience.

Table 3: Farming Experience of Farmer Borrowers and Repayment Rate

\begin{tabular}{|l|l|l|l|l|}
\hline Range( Years) & Frequency & \% & Repayment Rate \\
\hline & & & $\mathbf{1}-\mathbf{9 9 \%}$ & $\mathbf{1 0 0 \%}$ \\
\hline $5-15$ & 16 & 22.8 & 2 & - \\
$16-25$ & 32 & 45.7 & 5 & 5 \\
26 & 14 & 20.0 & 8 & 12 \\
$>30$ & 8 & 11.4 & 10 & 28 \\
\hline Total & $\mathbf{7 0}$ & $\mathbf{1 0 0}$ & $\mathbf{2 5}$ & $\mathbf{4 5}$ \\
\% & & & $\mathbf{3 5 . 7 \%}$ & $\mathbf{6 4 . 2 \%}$ \\
\hline
\end{tabular}

The table shows that farmers with the highest number of years of farming experience had the highest repayment capacity. 
Table 4: Repayment Rate of Farmer Borrowers by Educational Level

\begin{tabular}{|l|l|l|l|l|}
\hline Level of Education & Frequency & \% & \multicolumn{2}{|l|}{ Repayment Rate } \\
\hline & & & $\mathbf{1 - 9 9 \%}$ & $\mathbf{1 0 0 \%}$ \\
\hline No formal education & 14 & 20 & 8 & 4 \\
Primary School Education & 34 & 48.57 & 14 & 12 \\
$\begin{array}{l}\text { Secondary School Education } \\
\text { Above Secondary School Education }\end{array}$ & 18 & 25.71 & 8 & 15 \\
& 4 & & & \\
\hline Total & $\mathbf{7 0}$ & 5.71 & 11 & 8 \\
$\mathbf{\%}$ & & $\mathbf{1 0 0}$ & $\mathbf{3 1}$ & $\mathbf{3 9}$ \\
\hline
\end{tabular}

The analysis of the educational background of farmers in the study area is of importance so as to determine whether the ability of the farmer borrower to effectively manage loan is related to their level of education or not. The result shows that repayment rate is not related to farmer's educational background.

The results of regression analysis performed to test the effect of the independent variables $\left(\mathrm{X}_{1}\right.$, --- $\left.\mathrm{X}_{5}\right)$ on repayment are presented on table 5. Of the three models tried, the linear model was chosen, although the semi logarithmic gave a comparatively high $\mathrm{R}_{2}$ value, the signs of the coefficients were not consistent with the a priori expectation. The independent variables which were regressed against the dependent variables repayment rate $(\mathrm{Y})$ including age $\left(\mathrm{X}_{1}\right)$ household size $\left(\mathrm{X}_{2}\right)$ farming experience $\left(\mathrm{X}_{3}\right)$ level of education $\left(\mathrm{X}_{4}\right)$ and marital status $\left(\mathrm{X}_{5}\right)$ was included as a dummy variable.

Table 5: Regression Result of Rate of Repayment among Farmer Borrowers

\begin{tabular}{|c|c|c|c|c|}
\hline Variable & $\begin{array}{l}\text { Regression } \\
\text { Coefficient }\end{array}$ & $\begin{array}{l}\text { Standard } \\
\text { Error }\end{array}$ & t-Value & $\begin{array}{ll}\text { Level } & \text { of } \\
\text { Significant }\end{array}$ \\
\hline Age $\left(\mathrm{X}_{1}\right)$ & 0.65125 & 0.20916 & 3.0535 & $0.01 \& 0.05$ \\
\hline Household size $\left(\mathrm{X}_{2}\right)$ & -2.40226 & 0.45815 & -4.908 & $0.01 \& 0.05$ \\
\hline Level of Education $\left(\mathrm{X}_{3}\right)$ & 0.07541 & 0.26624 & 0.2808 & NS \\
\hline Farming Experience $\left(\mathrm{X}_{4}\right)$ & 0.62 & 0.00013 & 4.6164 & $0.01 \& 0.05$ \\
\hline Marital Status $\left(\mathrm{X}_{5}\right)$ & -0.12201 & 0.2661 & 0.2808 & NS \\
\hline $\begin{array}{ll}\text { Intercept, } & \mathrm{b}_{0}=83.26401 \\
& \mathrm{R}^{2}=0.621326 \\
& \mathrm{R}^{2}=0.584211\end{array}$ & & $\begin{array}{l}l=13.807 \\
\text { at } 0.01=2 \\
\text { at } 0.05=\end{array}$ & & \\
\hline
\end{tabular}

From the table above the variables age (X1) household Size (X2) and farming experience (X3) were significant at 0.01 and 0.05 probability levels. The null hypothesis that these variables do not have significant effect on loan repayment rate $(\mathrm{Y})$ was therefore rejected. The other variables, level of education and marital status X5 were both insignificant at 0.01 and 0.05 levels. The null hypothesis was therefore retained. The estimated regression line was

$\mathrm{Y}=83.264+0.65125 \mathrm{X}_{1}-2.30226 \mathrm{X}_{2}+0.07541 \mathrm{X}_{3}+0.00062 \mathrm{X}_{4}-0.12201 \mathrm{X}_{5}$

Se $0.20916 \quad 0.458180 .266240 .000130 .26621$

Where $\mathrm{SE}=$ Standard Error

$$
\begin{aligned}
& \mathrm{N}=70 \text { (sample size) } \\
& \mathrm{R} 2=0.621326 \\
& \mathrm{R}_{2}{ }^{2}=0.584211 \\
& \text { F-cal }=13.80765
\end{aligned}
$$

\section{Summary and Recommendation}

The study was on social life of cocoa farmers that affect their loan repayment capacity. Ikom Local Government Area of Cross River State was used for the study as majority of the farmers are involved in cocoa production and most of them use credit facility. Multistage random sampling was used for selecting the subjects. 70-cocoa farmers who during the 2004 farming seasons made use of loan were used for the study.

Results of the study showed that the farmers made use of loans for different purposes such as wages for labour, purchase of chemicals, payment for processing etc. Percentage of full repayment of loans decreased as household size increased. That of educational level did not follow a particular trend. Regression analysis showed that age and farming experience were positive. Household size and marital status were negative. Age, household size and farming experience were significant while level of education and marital status were insignificant. 


\section{Recommendation}

Social life of farmers should be duly considered when disbursing loans to them. Particularly age, household size and farming experience should constitute major criteria for loan disbursement, as these will aid loan repayment.

\section{References}

Arene, J. C. (1990) "Evaluation of the Performance of Supervised Agricultural Credit Scheme of Anambra State, Nigeria" UnpublishedPh.D Thesis. Department of Agricultural Economics, University of Nigeria, Nsukka.

Balogun, E. O. \& M. O. Otu (1991) "Credit Policies and Agricultural Development in Nigeria". Economics and Financial Review 29 (2), 138 - 155.

Majieha, R. D. (1991) "The demand and delinquency problem of formal agricultural loans: A case study of small holder farmers in Owerri agricultural zone of Imo State". Unpublished M.Sc Thesis.Department of Agricultural Economics, University of Nigeria, Nsukka. 